\title{
CONCENTRATION OF MS MEDIUM AND CUTTING OF SEEDS ON IN VITRO ESTABLISHMENT OF BARUZEIRO (Dipteryx alata Vog.)
}

\author{
CONCENTRAÇÃO DO MEIO MS E CORTE DA SEMENTE NO \\ ESTABELECIMENTO IN VITRO DO BARUZEIRO (Dipteryx alata Vog.)
}

\section{Hernane Fernandes PINHAL ${ }^{1}$; Elequisandra da Costa ARARUNA ${ }^{2}$; Pedro Augusto Porto CARNEIRO ${ }^{3}$; Simone Abreu ASMAR ${ }^{4}$; Berildo de MELO ${ }^{5}$; José Magno Queiroz LUZ}

1. Doutorando em Agronomia (Fitotecnia), Programa de Pós-Graduação em Agronomia, Universidade Federal de Uberlândia, Uberlândia, MG, Brasil. hernane@agronomo.eng.br; 2. Doutora em Agronomia (Fitotecnia); 3. Mestre em Agronomia (Fitotecnia; 4. Pós-doutoranda em Agronomia (Fitotecnia), Instituto de Ciências Agrárias, Universidade Federal de Uberlândia, Uberlândia, MG, Brasil; 5. Doutor em Agronomia (Fitotecnia), Professor Titular, Instituto de Ciências Agrárias, Universidade Federal de Uberlândia, Uberlândia, MG, Brasil.jmagno@ufu.br

\begin{abstract}
Savannah is the second biome in biodiversity in Brazil, presenting great vegetation endemism. Baruzeiro (Dipteryx alata Vog.), native from this biome, is an economically important species, with an incipient market due to the lack of commercial plantations. This highlights the need to develop and provide the basis for the domestication of this species. Thus, this study evaluated different concentrations of MS medium, using baruzeiro intact or cut seeds for in vitro establishment. Seeds from baruzeiro ripe fruits were decontaminated and were left intact or partially cut; subsequently, the seeds were inoculated into flasks with different concentrations of MS culture medium. The experimental design was completely randomized as a 5 x 2 factorial, consisting of 5 MS medium concentrations $(0,25,50,75$ or $100 \%)$ and 2 types of seeds (intact or partially cut seeds), with three replications. Each experimental unit consisted of five flasks and 10 plants. After five months of incubation, the contamination of explants, seed germination, the number of fully developed plants and the dry masses of shoot and root of baruzeiros were evaluated. Intact seeds provided better results for all characteristics evaluated. The increased concentration of MS medium resulted in mass gain of plants; however, the use of MS medium $0 \%$ provided greater percentage of fully developed plants, the most interesting feature for baruzeiro in vitro establishment.
\end{abstract}

KEYWORDS: In vitro culture. Culture medium. Explant.

\section{INTRODUCTION}

Baruzeiro (Dipteryx alata Vog.) is a naturally occurring fruit tree of the Savannah, and deserves special attention due to a series of interesting characteristics that allows commercial use, with fruits and seeds considered regionally as a choice nut. However, studies are needed to contribute for the cultivation of this tree, in order to aid in the species dissemination.

In vitro cultivation is an interesting alternative for baruzeiro propagation, since it satisfactorily contributes for a quality seedling production system with high efficacy. Moreover, thinking about species protection, techniques for in vitro germplasm conservation are a relevant alternative due to the difficulty of maintaining natural areas and of creating orchards. In vitro preservation allows the use of reduced spaces and easiness of plant maintenance. Another benefit consists in the fact that in vitro conservation, in comparison with seed preservation methods, results in greater longevity of conservation when ideal techniques are established for this purpose.
One aspect that must be observed carefully on in vitro growth is the cultivation medium composition, since it must supply all required components for plant development, besides presenting characteristics that allow complete explant adaptation and growth.

Besides the selection of a growth medium best adapts to the explant, it is necessary to determine de most adequate concentration of this medium, because, even when the medium contains all nutrients demanded by the plant, its concentration can affect the ability of the plant to extract nutrients and water, essential for in vitro adaptation of the species.

The study of growth media with low nutrient concentration is interesting, since reducing the amount of salts in the medium is a strategy to limit plant in vitro growth aiming at germplasm conservation.

When explant establishment occurs from in vitro germination, determination of seed sanitary conditions becomes important, since external layers of the seed behave as physical barriers hindering 
water and nutrient absorption which are necessary for germination and plantlet development.

Martinotto et al. (2001) completely removed the tegument of Eugenia dysenterica DC. (cagaiteira), to allow the in vitro establishment of the species. Lameira et al. (2000) scarified Schizolobium amazonicum (paricá) seeds, a native plant of the same family as baruzeiro and increased in vitro germination of that species.

Partial removal of external seed barriers, even for species that have no dormancy, can maximize plant in vitro adaptation because such barriers may hinder absorption of water and nutrient in more concentrated media.

The greatest challenge in developing a protocol for in vitro cultivation of baruzeiro is the lack of specific studies about this theme. Thus, publishing information, especially about the initial protocol choices, will be a milestone for new studies of this species.

Therefore, this study evaluated different concentrations of medium MS, using intact or cut Dipteryx alata (baruzeiro) seeds for in vitro establishment.

\section{MATERIAL AND METHODS}

The study was done at the Biotechnology Laboratory at the Instituto de Ciências Agrárias in Universidade Federal de Uberlândia, from Feburary to June 2012.

The experimental design was completely randomized, as a $5 \times 2$ factorial, with five MS medium concentrations $(0,25,50,75$ or $100 \%)$ and two seed treatments (intact or cut seeds), with three replications. Each experimental unit consisted of five flasks, each containing two seeds.

The seeds used as explants were removed from ripe fruits, collected in September 2011, at Fazenda Água Limpa, of Universidade Federal de Uberlândia and located on Road MG-455, km 18. The fruits were stored in aired placed, protected from direct sunlight. On the day previous to experiment assembly, the seeds were removed from the fruits with a bench vice.

Seeds were washed in tap water with neutral liquid detergent for five minutes before inoculation in the growth media. Subsequently, seeds were taken to a flow hood and, according to the specified treatment, were maintained intact, or were cut, with a scalpel, removing $1 / 4$ of the seed, in the region opposite to that of the embryo. Asepsis was done by dipping the seeds in ethanol $70 \%\left(\mathrm{v} \mathrm{v}^{-1}\right)$ for one minute and transferring them to a sodium hypochloride solution at $2 \%\left(\mathrm{v} \mathrm{v}^{-1}\right)$ for 20 minutes.
Disinfested seeds were inoculated into 150$\mathrm{mL}$ glass flasks containing $50 \mathrm{~mL}$ of MS medium (MURASHIGE; SKOOG, 1962) supplemented with $0.4 \mathrm{mg} \mathrm{L}^{-1}$ thiamine; $1 \mathrm{mg} \mathrm{L}^{-1}$ pyridoxine; $0.5 \mathrm{mg} \mathrm{L}^{-}$ ${ }^{1}$ nicotinic acid; $100 \mathrm{mg} \mathrm{L}^{-1}$ mio-inositol and $0.5 \mathrm{~g} \mathrm{~L}^{-}$ ${ }^{1}$ hydrolyzed casein, diluted for the concentration defined in each treatment. Regardless of medium concentration, $30 \mathrm{~g} \mathrm{~L}^{-1}$ sucrose, $3 \mathrm{~g} \mathrm{~L}^{-1}$ activated charcoal, $8 \mathrm{~g} \mathrm{~L}^{-1}$ agar were added, and $\mathrm{pH}$ adjusted to 5.7 .

The inoculation process was done under aseptic condition in a sterile environment. The flasks, with baruzeiro seeds, were capped with plastic lids and transferred to a growth room, remaining there for five months at $25^{\circ} \mathrm{C}$ and with 16 hours lighting at an intensity of $25 \mu \mathrm{mol} \mathrm{m} \mathrm{s}^{-2}$.

Explant development was monitored daily and, at the end of incubation period, were evaluated for contamination, seed germination, number of explants completely developed and shoot and root dry matter. Plant parts were dried in a forced air oven at 60 to $65^{\circ} \mathrm{C}$ until constant matter, with subsequent weighing in a precision scale.

Normality of residues and homogeneity of variances were tested by the Shapiro-Wilk's test ( $\alpha$ $=0.01)$ and Levene's test $(\alpha=0.01)$ using SPSS. Subsequently, the data were submitted to the analysis of variance $(\alpha=0.05)$ and the averages compared by the Tukey test $(\alpha=0.05)$ or compared by regression analysis $(\alpha=0.05)$, using SISVAR (FERREIRA, 2000).

\section{RESULTS AND DISCUSSION}

All characteristics evaluated presented normality of residues and homogeneity of variances. The concentration of MS medium affected germination, number of formed explants and shoot and root dry matter (Table 1). Partially cutting the seeds affected all characteristics evaluated and, for contamination, this effect was observed only in the interaction matter.

The analysis of interaction effect between MS medium concentration and intact or partially cut seeds for explant contamination indicated that medium concentration affected contamination only when cut seeds were used (Figure 1). In this case, concentrations near $50 \%$ reduced contamination level, and more contamination was observed in media either more concentrated or diluted. Nutrient concentration in the growth medium can interfere on pathogen development in this environment. However, this effect is variable, according to the plant used and to experiment conditions, since Rocha et al. (2007), working with peach, found the 
lowest contamination level using MS 75\%, in comparison to the same medium at 50 or $100 \%$.

Table 1. Summary of analyses of variance for the percentage of contamination, germination, formed plants, dry matter of shoots (MSPA) and dry matter of roots (MSR) of baruzeiro (Dipteryx alata Vog.) explants grown in vitro.

\begin{tabular}{ccccccc}
\hline Source of Variation & \multirow{2}{*}{ DF } & \multicolumn{5}{c}{ Mean Squares } \\
\cline { 3 - 7 } & & Contamination & Germination & Formed Plants & MSPA & MSR \\
\hline MS medium & 4 & $0.04^{\mathrm{ns}}$ & $0.03^{\mathrm{ns}}$ & $0.11^{* *}$ & $0.11^{* *}$ & $0.29^{* *}$ \\
concentration & 1 & $0.03^{\mathrm{ns}}$ & $0.15^{* \mathrm{~s}}$ & $0.25^{* *}$ & $1.03^{* *}$ & $1.07^{* *}$ \\
$\quad \begin{array}{c}\text { Seed } \\
\text { Concentration X Seed }\end{array}$ & 4 & $0.11^{*} \mathrm{~s}$ & $0.03^{\mathrm{ns}}$ & $0.07^{\mathrm{ns}}$ & $0.21^{* *}$ & $0.10^{\mathrm{ns}}$ \\
Residue & 29 & $0.03^{\mathrm{ns}}$ & $0.03^{\mathrm{ns}}$ & $0.04^{\mathrm{ns}}$ & $0.12^{* *}$ & $0.09^{\mathrm{ns}}$ \\
\hline $\mathbf{C V}(\%)$ & & $53.84^{\mathrm{ns}}$ & $20.44^{\mathrm{ns}}$ & $26.53^{\mathrm{ns}}$ & $22.64^{\mathrm{ns}}$ & $28.14^{\mathrm{ns}}$ \\
\hline
\end{tabular}

ns non-significant by the $\mathrm{F}$ test at $5 \%$ probability; * significant by the $\mathrm{F}$ test at $5 \%$ probability.

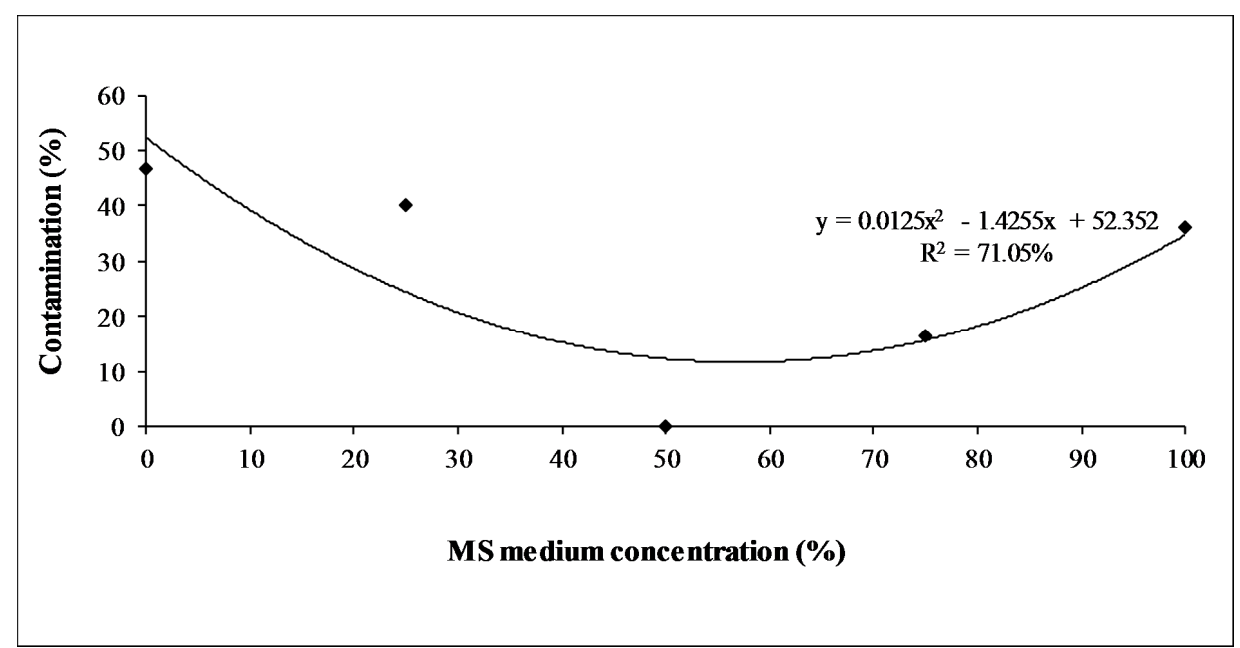

*Regression Analysis $(\alpha=0.05)$

Figure 1. Contamination of baruzeiro (Dipteryx alata Vog.) explants as a function of MS medium concentration for cut seeds.

Cut seeds presented the lowest contamination levels only when MS 50\% was used (Figure 2). The other media concentrations resulted in similar contamination levels for both seed types.

Germination was a characteristic affected by cutting the seed (Figure 2), regardless of MS medium concentration. Partially cutting the seed or completely removing its tegument has been used for in vitro cultivation of other species, with advantages; however, this practice is commonly related to the difficulty of some seeds to germinate when maintained intact (LAMEIRA et al., 2000; VAL et al., 2010). Since baruzeiro has no germination restriction with intact seeds, with germination of $88.27 \%$, such sectioning of seeds could be harmful, since it causes injuries to the seed, compromising its development, besides the loss of part of nutrient reserves of the seed, which are important in early in vitro germination stages of this fruit species.

The negative effect of seed cutting was also observed in the number of completely developed plants, with $79.93 \%$ for intact seeds, in contrast with $71.60 \%$ for cut seeds (Figure 2). Costa et al. (2010) also found better germination indices for nonscarified Passiflora setacea D.C. seeds, since for this plant the tegument was not a physical barrier against water absorption, similar to baruzeiro.

As MS medium concentration increased, a proportional decrease in the number of formed plants was observed, suggesting that, even though seed germination was not affected, the reduction in medium salt concentration may favor water absorption by the plant, improving its development (Figure 3). Several studies report the benefits of 
using less concentrated MS medium. Jelly palm, Butia capitata (Mart.) Becc., was favored by reducing MS concentration to 75\% (RIBEIRO et al., 2011). In vitro germination of Inga vera Willd. subsp. affinis (DC.) T.D. Penn. in half strength MS medium was better than that in full strength MS
(STEIN et al., 2007). Martendal et al. (2013) reported that a growth medium containing only water and agar was the most effective for in vitro germination of zygote embryos of murici (Byrsonima cydoniifolia A. Juss.).

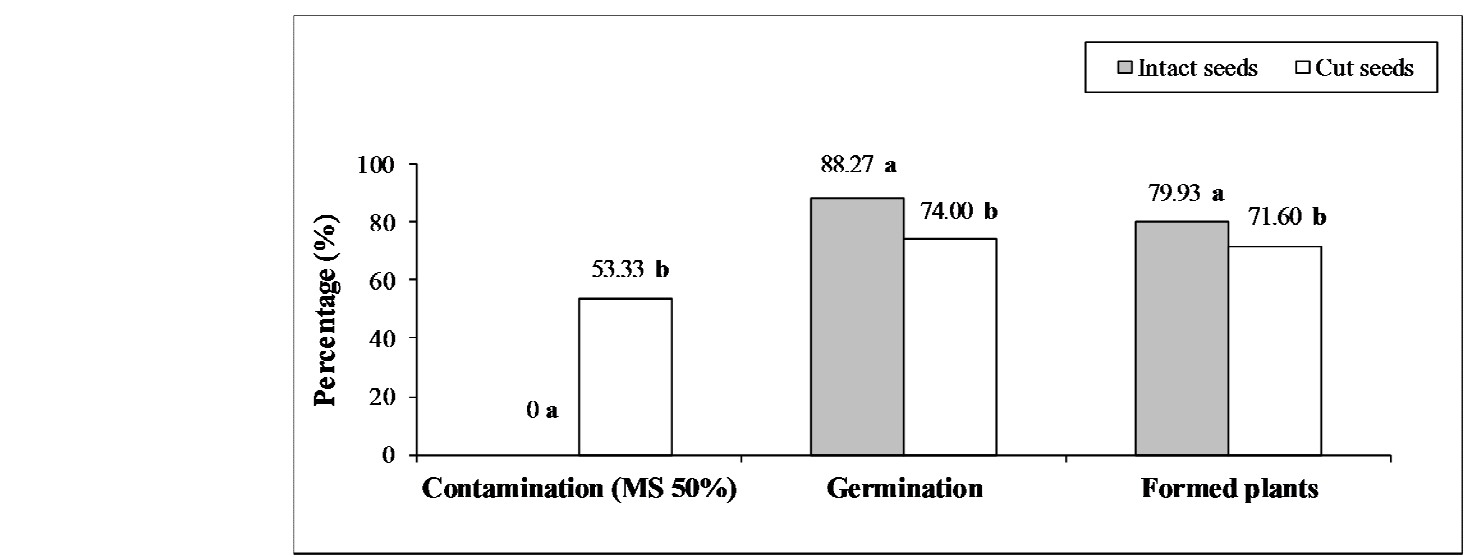

*Averages followed by different letters for a given variable are different by the F test $(\alpha=0.05)$ and Tukey test $(\alpha=0.05)$.

Figure 2. Percentage of contamination (in MS medium 50\%), germination and formed explants, from intact or cut baruzeiro (Dipteryx alata Vog.) seeds grown in vitro.

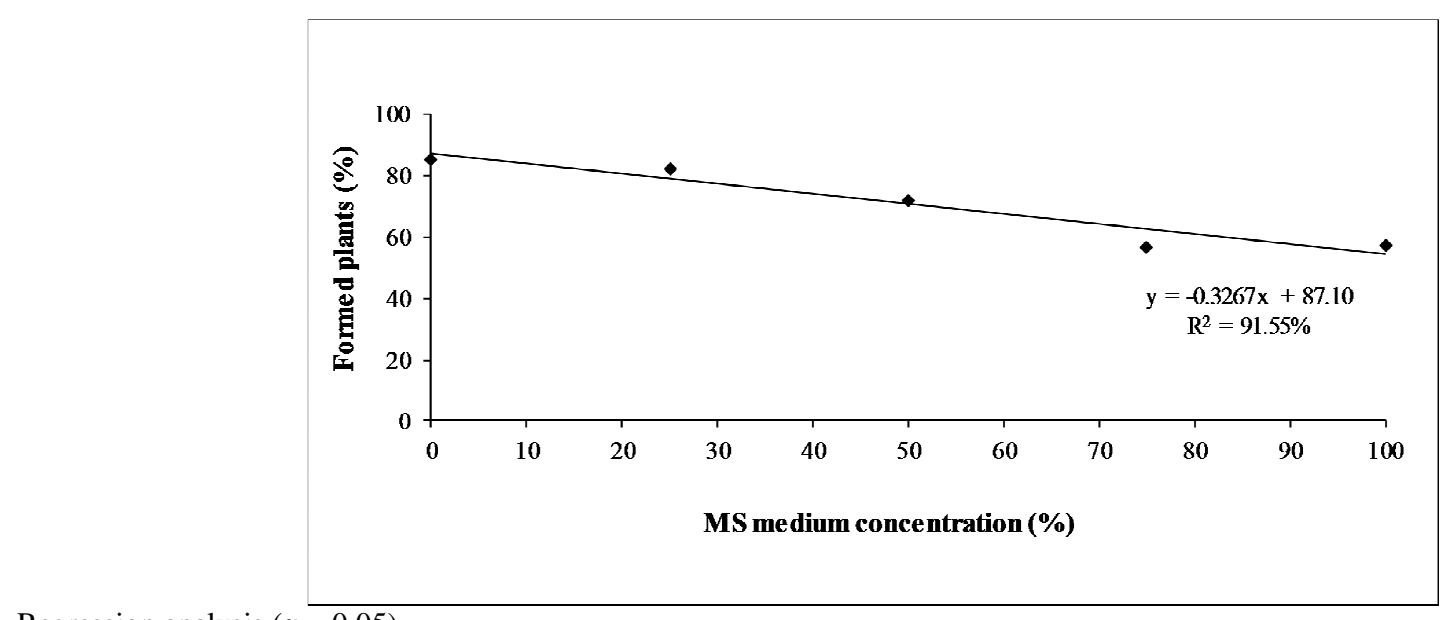

Regression analysis $(\alpha=0.05)$.

Figure 3. Percentage of completely in vitro formed plants of baruzeiro (Dipteryx alata Vog.) in different concentrations of MS medium.

However, it is important to observe that the relation between plantlet development and medium concentration is inherently connected to each species nutritional requirements of the explant used for the in vitro growth stage, since for node segments of blackberry 'Xavante', increasing MS concentration to $125 \%$ was positive (LEITZKE et al., 2009).

It is important to note that, in all plantlets of the experiment, the cotyledons were partially consumed, demonstrating that the reserve material of the own seed was able to supply nutrients until its establishment. Thus, observing explant behavior in the different medium concentrations containing only water, supplemented with sucrose, activated charcoal, and agar (medium MS 0\%) was viable, which is positive since this is the most economical and practical medium, and could be evaluated for in vitro germplasm conservation to increase explant longevity in the startup growth medium.

Sectioning the seeds resulted in a reduction in shoot dry matter (Figure 4), after growth in MS at 75 and $100 \%$, concentrations in which partially sectioning the seeds showed significant effect. Also, 
root dry matter was reduced in this treatment (Figure 5). Such reduction in matter could be a consequence of reduced seed reserves, as noted previously, which effectively contributed for poorer plant growth and formation.

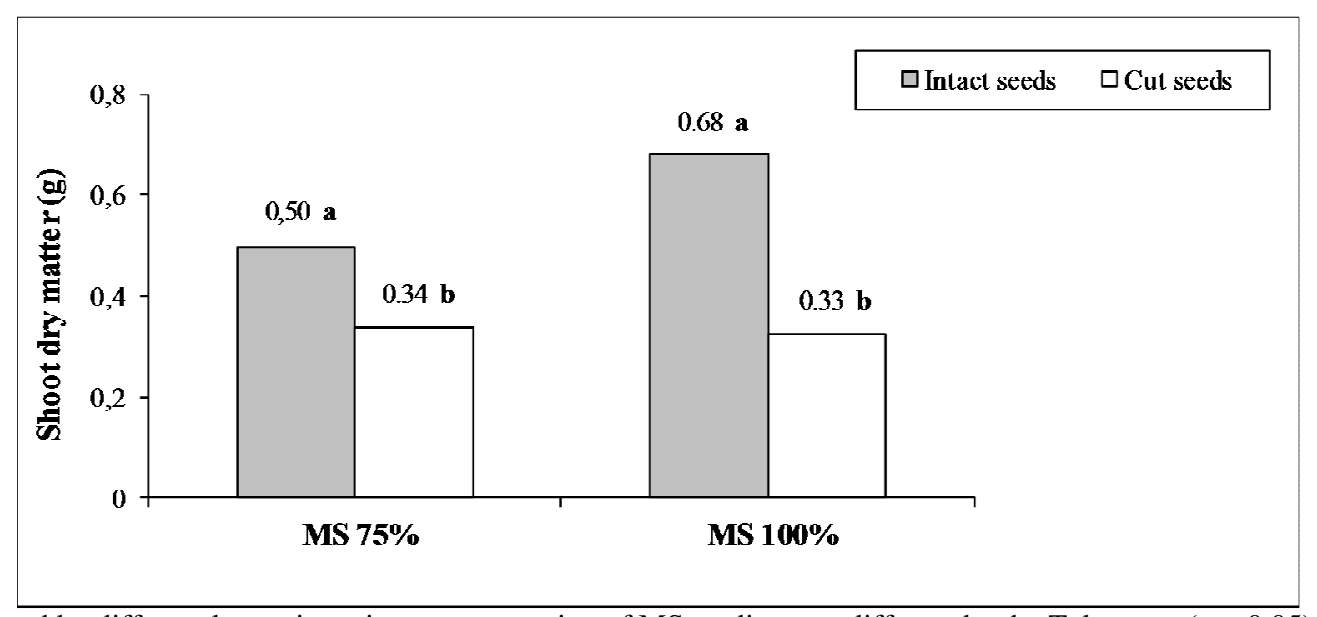

*Averages followed by different letters in a given concentration of MS medium are different by the Tukey test $(\alpha=0.05)$.

Figure 4. Shoot dry matter of baruzeiros (Dipteryx alata Vog.) in vitro formed from intact or cut seeds in MS medium at 75 and $100 \%$ concentration.

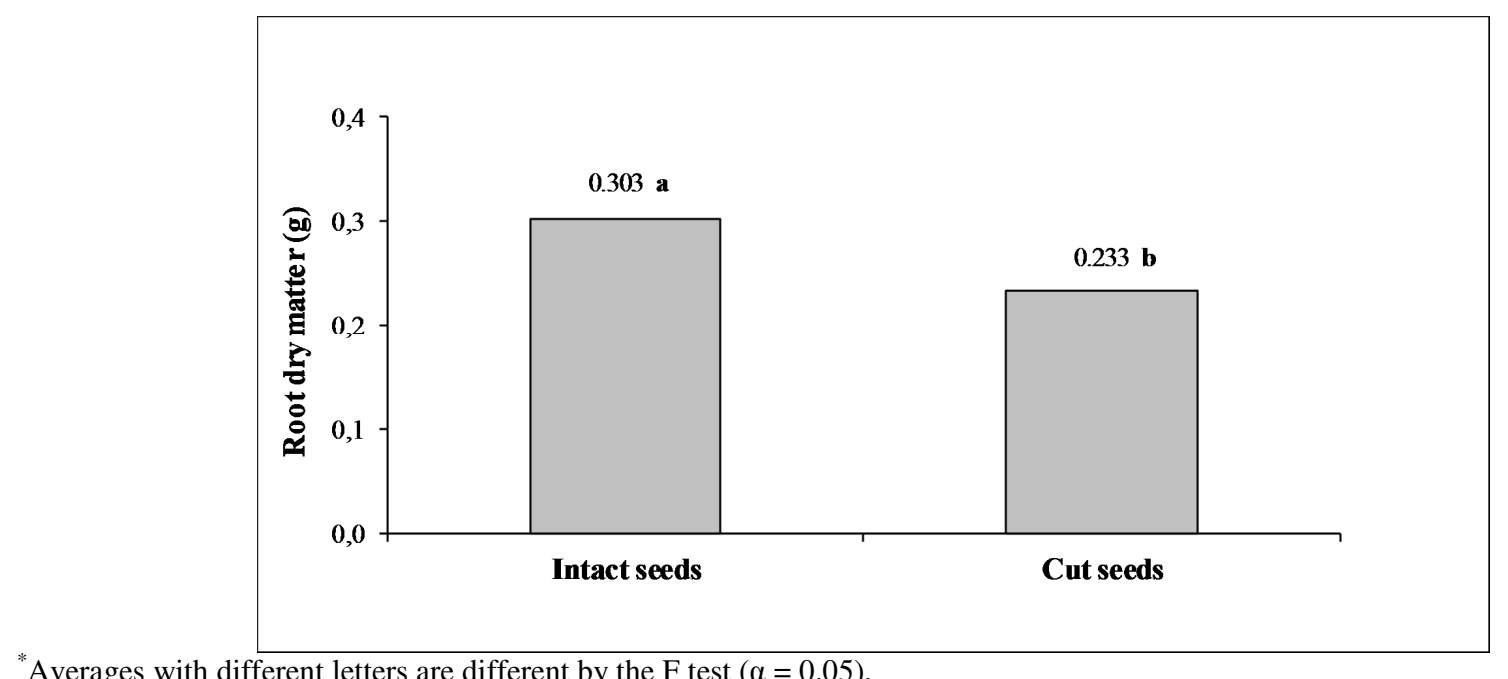

*Averages with different letters are different by the $\mathrm{F}$ test $(\alpha=0.05)$.

Figure 5. Root dry matter of baruzeiros (Dipteryx alata Vog.) in vitro formed from intact or cut seeds.

The concentration of MS medium affected only shoot dry matter of intact seeds. In this treatment, shoot dry matter increased as MS concentration also increased (Figure 6). This might be related to nutrient availability in more concentrated media, favoring explant shoot development. This is in agreement with the study of Oliveira et al. (1996) with chrysanthemum 'Orange Reagen', when greater values of shoot dry matter were found in more concentrated MS media.
Increasing concentrations of MS medium contributed for increased root dry matter until a maximum (MS at 69.22\%), and dropped from that point on (Figure 7). Such results differ from those found by Couto et al. (2003), who found no effect of MS concentration on rooting of peach 'Barrier'. Ribeiro et al. (2011), in contrast, obtained results similar to those found for baruzeiro after growing jelly palm in increasing concentrations of MS medium, with optimum at $75 \%$. 


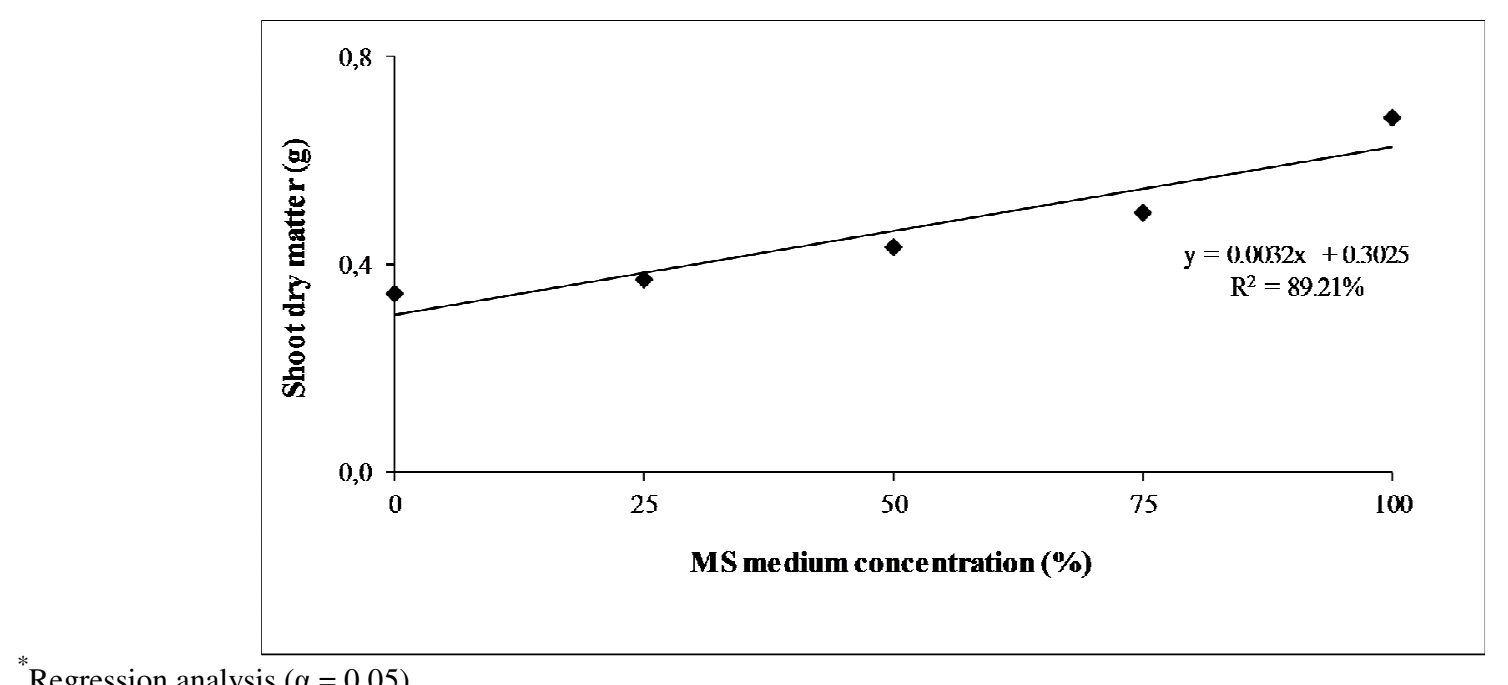

*Regression analysis $(\alpha=0.05)$.

Figure 6. Dry matter of shoots of baruzeiro (Dipteryx alata Vog.) in vitro formed from intact seeds in different MS medium concentrations.

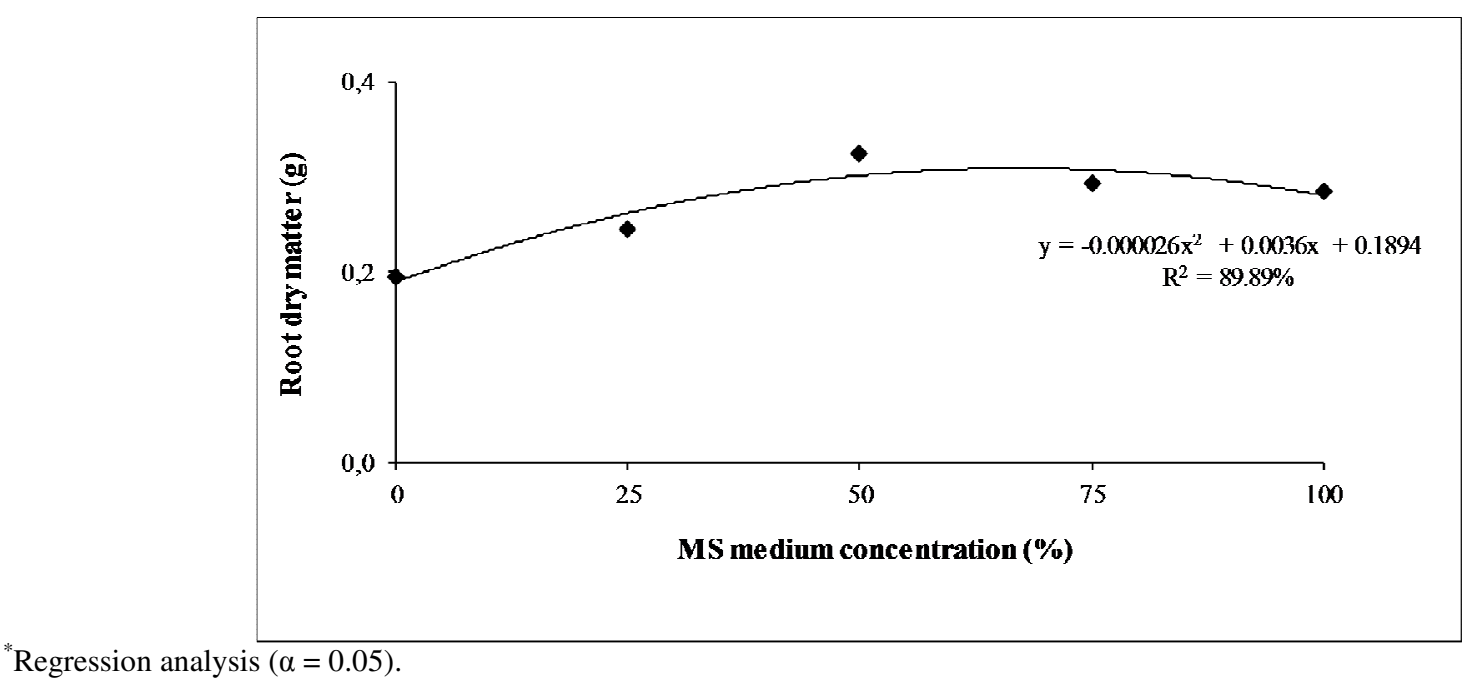

Figure 7. Dry matter of roots of baruzeiro (Dipteryx alata Vog.) in vitro in different MS medium concentrations.

It is important to highlight that, even though there were treatments favoring root and shoot growth, all formed plants presented excellent formation and root and shoot growth, resulting in explant mass gain in all MS concentrations evaluated for in vitro plant establishment.

Therefore, although greater concentrations of MS medium resulted in increased plant mass, growing the plants in the medium containing only sucrose, activated charcoal and agar (MS 0\%) was the best option because it more effectively favored baruzeiro plants, which is the most desired characteristic for in vitro establishment stage. The use of intact seeds is a rather interesting option, since cutting a part off reduced the seed 's natural reserve, which is essential for plant development, also allowing growth in MS medium with very low nutrient availability.

\section{CONCLUSIONS}

The use of intact seeds favors in vitro baruzeiro (Dipteryx alata Vog.) establishment.

The lower the concentration of MS medium, the greater the percentage of formed in vitro baruzeiro plants.

The use of a growth medium containing only water supplemented with sucrose, agar and 
activated charcoal represents the best option for in vitro growth of baruzeiro, since it is an effective, practical and economical system, besides the perspective of using it for the study of in vitro germplasm conservation.

\section{ACKNOWLEDGEMENTS}

The authors are indebt to CAPESCoordenação de Aperfeiçoamento de Pessoal de Nível Superior, to CNPq-Conselho Nacional de Desenvolvimento Científico e Tecnológico and to FAPEMIG-Fundação de Amparo a Pesquisa do Estado de Minas Gerais for the financial support.

RESUMO: O Cerrado é o segundo bioma em biodiversidade do Brasil, apresentando grande endemismo vegetal. O baruzeiro (Dipteryx alata Vog.) é uma espécie economicamente importante, com mercado incipiente devido à escassez de cultivos comerciais. Isto deixa notória a necessidade de desenvolver e aperfeiçoar subsídios para a domesticação dessa espécie. Assim, neste trabalho, objetivou-se avaliar diferentes concentrações do meio MS, utilizando sementes de baruzeiro (Dipteryx alata Vog.) íntegras e com corte para o estabelecimento in vitro. Sementes retiradas de frutos maduros de baruzeiro foram descontaminadas e mantidas intactas ou receberam cortes parciais, sendo posteriormente inoculadas em frascos, com diferentes concentrações de meio de cultivo MS. O experimento foi instalado em sistema de delineamento inteiramente casualizado em esquema fatorial 5 x 2 - meio MS (0, 25, 50, 75 e 100\%) x tipos de sementes (sementes íntegras e sementes com corte) com três repetições, totalizando 30 parcelas. Cada unidade experimental foi constituída de cinco frascos e 10 plantas. Após cinco meses, foram avaliados: a contaminação dos explantes, a germinação das sementes, o número de plantas totalmente desenvolvidas e as massas secas da parte aérea e da raiz dos baruzeiros. As sementes íntegras proporcionaram melhores resultados, para todas as características avaliadas. $\mathrm{O}$ aumento da concentração do meio MS colaborou no ganho de massa das plantas, no entanto, o uso do meio MS $0 \%$ foi o que proporcionou maior percentual de plantas formadas, a característica mais interessante para o estabelecimento in vitro do baruzeiro.

PALAVRAS-CHAVE: Cultivo in vitro. Meio de cultura. Explante.

\section{REFERENCES}

COSTA, C. J.; SIMÕES, C. O.; COSTA, A. M. Escarificação mecânica e reguladores vegetais para superação da dormência de sementes de Passiflora setacea D.C. Planaltina: Embrapa Cerrados, 2010 (Boletim de Pesquisa e Desenvolvimento, 271).

COUTO, M.; WAGNER JUNIOR, A.; QUEZADA, A. C. Enraizamento in vitro do porta-enxerto de Prunus sp. 'Barrier' em diferentes concentrações de ácido indol-3-butirico (AIB) e do meio Murashige \& Skoog (MS). Revista Brasileira de Agrociência, Pelotas, v. 9, p. 367-370, 2003.

FERREIRA, D. F. Análise estatística por meio do SISVAR (Sistema para Análise de Variância) para Windows versão 4.0. In: REUNIÃO ANUAL DA REGIÃO BRASILEIRA DA SOCIEDADE INTERNACIONAL DE BIOMETRIA, 45, 2000, São Carlos. Anais... São Carlos: UFSCar, 2000. p. 255-258.

LAMEIRA, O. A.; GOMES, A. P. R.; LOPES, S. C.; LEÃO, N. V. M. Efeito da escarificação sobre a germinação de sementes de paricá (Schizolobium mazonicum) in vitro. Belém: Embrapa Amazônia Oriental, 2000. n. 21 (Comunicado Técnico, 21).

LEITZKE, L. N.; DAMIANI, C. B.; SCHUCH, M. W. Multiplicação e enraizamento in vitro de amoreira-preta 'Xavante': efeito da concentração de sais, do tipo de explante e de carvão ativado no meio de cultura. Ciência e Agrotecnologia, Lavras, v. 33, p. 1959-1966, 2009. https://doi.org/10.1590/s1413-70542009000700045

MARTENDAL, C. O.; BERNARDINO, M. M.; PEREIRA, F. D.; SILVA, F. G.; EVANGELISTA DE MENEZES, C. C.; HARA, A. C. B. A. M. In vitro cultivation of zygotic embryos from Murici (Byrsonima cydoniifolia A. Juss.): establishment, disinfection, and germination. Acta Scientiarum. Agronomy, Maringá, v. 35, n. 2, p. 221-229, 2013. https://doi.org/10.4025/actasciagron.v35i2.15402 
MARTINOTTO, C.; PAIVA, R.; SANTOS, B. R.; SOARES, F. P.; NOGUEIRA, R. C.; MURASHIGE, T.; SKOOG, F. A revised medium for rapid growth and biossays with tabacco tissue cultures. Physiologia Plantarum, Copenhagen, v. 15, p. 473-497, 1962. https://doi.org/10.1111/j.1399-3054.1962.tb08052.x

OLIVEIRA, P. D.; PASQUAL, M.; PAIVA, R. Efeito de diferentes concentrações do meio MS, nitrogênio e sacarose na micropropagação de crisântemo 'orange reagen'. Bragantia, Campinas, v. 55, n. 1, p. 9-18, 1996. https://doi.org/10.1590/S0006-87051996000100002

RIBEIRO, L. M.; NEVES, S. C.; SILVA, P. O.; ANDRADE, I. G. Germinação de embriões zigóticos e desenvolvimento in vitro de coquinho-azedo. Revista Ceres, Viçosa, v. 58, n. 2, 133-139, 2011.

ROCHA, P. S. G.; SCHUCH, M. W.; BIANCHI, V. J.; FACHINELLO, J. C.; MISTURA, C. C. Estabelecimento in vitro de porta-enxertos de pessegueiros em diluições do meio MS acrescido de concentrações de BAP. Bioscience Journal, Uberlândia, v. 23, n. 4, p. 83-87, 2007.

SILVA, A. A. N. Efeito da escarificação e luminosidade na germinação in vitro de sementes de cagaiteira (Eugenia dysenterica DC.). Ciência e Agrotecnologia, Lavras, v. 31. p 1668-1671, 2001.

STEIN, V. C.; PAIVA, R. S.; NOGUEIRA, F. P.; SILVA, R. C.; COUTINHO, L.; EMRICH, E. Germinação in vitro e ex vitro de Inga vera Willd. subsp. affinis (DC.) T.D. Penn. Ciência e Agrotecnologia, Lavras, v. 31, p. 1702-1708, 2007.

VAL, A. D. B.; MOTOIKE, S. Y.; ALVARENGA, E. M.; CECON, P. R. Quebra de dormência de sementes da videira cv. niágara rosada sem estratificação. Revista Ceres, Viçosa, v. 57, n. 2, p. 234-238, 2010. 